\title{
Impact of anthropogenically created canopy gaps on wave attenuation in a Posidonia oceanica seagrass meadow
}

\author{
J. Colomer ${ }^{1, *}$, M. Soler ${ }^{1}$, T. Serra ${ }^{1}$, X. Casamitjana ${ }^{1}$, C. Oldham ${ }^{2}$ \\ ${ }^{1}$ Department of Physics, University of Girona, 17003 Girona, Spain \\ ${ }^{2}$ School of Civil, Environmental and Mining Engineering, the University of Western Australia, Crawley, WA 6009, Australia
}

\begin{abstract}
Fixed weights moorings, once removed, can create longitudinal gaps in seagrass meadows of different sizes, running perpendicular to the coast. We quantified the interactions between these longitudinal gaps and the hydrodynamic environment of the nearshore environment to determine their potential impact on seagrass meadow ecology. Within the meadow at leaf length distances from the edge, wave attenuation by the lateral vegetation next to the gap was approximately the same as attenuation by fully vegetated areas, and the wave attenuating capacity of the lateral, near-gap vegetation was independent of gap width. Gaps with widths less than twice the leaf length exhibited $8 \%$ wave attenuation and $11 \%$ turbulent kinetic energy attenuation, confirming that vegetation shelters at least small gaps. Despite similar capacity for wave attenuation, the longitudinal gaps influenced the architectural characteristics of the adjacent (lateral) meadow; lateral shoot density, percent cover and leaf length adjacent to the largest gap were 12,16 , and $20 \%$ lower than the fully vegetated site, respectively. Significant differences in the temporal variation of the mean lateral, near-gap seagrass percent cover and the leaf length indicated a strong dependence of the state of the canopy on temporal hydrodynamic conditions, which in turn were impacted by the presence of the gap. Our results quantify the interactions between gaps and lateral meadow vegetation, highlight the structural impact of traditional moorings and support improved management and conservation of seagrass meadows.
\end{abstract}

KEY WORDS: Wave attenuation - Posidonia oceanica - Seagrass meadow - Mooring · Gaps · Edge effect $\cdot$ Seascape

\section{INTRODUCTION}

In the western Mediterranean, a typical Posidonia oceanica seagrass meadow consists of fairly continuous seafloor canopy, broken occasionally by vegetation-free gaps that are subject to erosion (sensu Patriquin 1975, Boudouresque et al. 2012). The gaps also frequently contain rhizome mattes buried in the sand that may support regrowth (Cabaço et al. 2008). Currents at the bottom erode the meadow, creating a vertical edge of matte, whereas on the other side $P$. oceanica colonizes the

\footnotetext{
${ }^{*}$ Corresponding author: jordi.colomer@udg.edu
}

bare sandy bottom (Boudouresque et al. 1980, Gobert et al. 2016). The balance between vegetative growth and spatial patchiness depends on the frequency and amplitude of natural disturbances (Duarte 1991, Cabaço et al. 2008); however, when human activities exceed the natural disturbance regime the balance may be upset, and vegetative growth may not compensate for meadow fragmentation (Montefalcone et al. 2010). For clarity, here we define 'patchiness' as the structure of a seascape at a time $t$, and 'fragmentation' as the evolution of patchiness through time.

() The authors 2017. Open Access under Creative Commons by Attribution Licence. Use, distribution and reproduction are unrestricted. Authors and original publication must be credited. 
The fragmentation of meadows leads to more complex seascapes and takes place via several mechanisms and over different spatial scales (Abadie et al. 2015). Moorings using anchors (anchoring) and fixed weights moorings (mooring) are one of the main causes of anthropogenic disturbances within seagrass meadows (Walker et al. 1989, Hastings et al. 1995, Montefalcone et al. 2008, Boudouresque et al. 2012, Demers et al. 2013, Giakoumi et al. 2015). Gaps caused by trawling and the anchoring of large boats have been found along the Mediterranean coast (Francour et al. 1999, Leriche et al. 2006) and nearshore mooring scars can increase the loss of sedimentary organic carbon stores (Serrano et al. 2016). The resulting habitat patchiness, where large stretches of habitat are removed or damaged, influences ecosystem integrity to the point that ecological function may be compromised (Larsen et al. 2008). Abadie et al. (2016) found that the anchoring impacts of large boats modified substrate quality, by increasing the hydrogen sulfide concentration, at a month scale. Vacchi et al. (2010) demonstrated the poor condition of $P$. oceanica meadows in the Ligurian Sea; although this has been attributed to anthropogenic impacts, natural factors, especially wave climate were also implicated. Indeed, in the Ligurian Sea there was a higher degree of $P$. oceanica meadow patchiness in the shallower zones (to about $14 \mathrm{~m}$ depth) in humanimpacted areas compared to meadows in natural areas (Montefalcone et al. 2010), highlighting a possible interaction between anthropogenic influences, wave climate and meadow health.

Wave-induced forces can control the distribution of seagrass populations (Gacia \& Duarte 2001, Madsen et al. 2001, Hansen \& Reidenbach 2013). Specifically, waves have been found to determine the upper (Infantes et al. 2009) and lower (Vacchi et al. 2012) depth distribution limits of $P$. oceanica and can also influence species, size and morphology (Lewis 1968, Menge 1976, Blanchette 1997). Several studies have demonstrated wave attenuation by $P$. oceanica meadows. Granata et al. (2001) found that at the edge of a $P$. oceanica canopy, with densities between 200 and 500 shoots $\mathrm{m}^{-2}$, the vertical reduction in kinetic energy (KE) ranged from 65 to $95 \%$. Infantes et al. (2012) measured wave heights and orbital velocities along a meadow, finding $50 \%$ attenuation of root mean squared wave heights in a meadow of $P$. oceanica with shoot density of 600 shoots $\mathrm{m}^{-2}$. Manca et al. (2012) showed that wave-induced flow attenuation within model $P$. oceanica meadows increased with increasing meadow density and was always larger within the meadow (59\%) than near the edge of the meadow $(12 \%)$. Similar flow attenuation was observed by Koftis et al. (2013) over artificial P. oceanica meadows of densities of 180 and 360 shoots $\mathrm{m}^{-2}$. Granata et al. (2001) showed that hydrodynamics may be reduced both under and above the canopies by 10 to $75 \%$. In summary, higher flow attenuation has been observed inside canopies with increasing shoot density (Leonard \& Luther 1995, Koch \& Gust 1999, Peterson et al. 2004, Nepf et al. 2007, Hansen \& Reidenbach 2012, Pujol et al. 2012, 2013a,b)

Pujol et al. (2013b) conducted oscillatory flow experiments in the laboratory using a submerged flexible canopy constructed to simulate $P$. oceanica properties. They found orbital velocity reductions of 22 and $39 \%$ for solid plant fractions (SPF; i.e. canopy densities) of $5 \%\left(640\right.$ shoots $\mathrm{m}^{-2}$ ) and $10 \%$ (1280 shoots $\mathrm{m}^{-2}$ ) respectively. They also found a $46 \%$ reduction in turbulent kinetic energy (TKE) in a dense canopy of $10 \%$ SPF compared to non-vegetated experiments, and a $34 \%$ reduction in TKE in an intermediate density (5\% SPF). Koftis et al. (2013) also found that wave orbital velocities were significantly attenuated inside a model canopy. Fonseca \& Callahan (1992) determined from flume experiments that seagrass canopies that occupy the entire water depth could reduce wave heights between 20 and $76 \%$. While canopy effects on the hydrodynamics inside a canopy have been clearly confirmed, conditions at the canopy edge are more variable (Gruber \& Kemp 2010). The edge of seagrass canopies is a dynamic region were both ambient hydrodynamics and sediment transport are modified (Fonseca et al. 1982, Granata et al. 2001, Tigny et al. 2007, Gruber \& Kemp 2010, Nepf 2012a,b) with non-linear responses to variable morphodynamics (Zhu et al. 2003, Fontan et al. 2013, Hu et al. 2014). Spatial fragmentation of meadows, whether natural or anthropogenic, dramatically increases the frequency of edges; however, the impact of fragmentation on hydrodynamic edge effects has been poorly documented. In a laboratory experiment, El Allaoui et al. (2016) studied the effects of canopy patchiness on the mixing level in a canopy and quantified the extent to which small gaps, oriented perpendicular to the wave direction, were sheltered by the canopy, and also the extent to which gap width impacted the degree of sheltering.

In the present field-based study, we assess the hydrodynamics within mooring-induced longitudinal gaps in a $P$. oceanica meadow, focusing on the effect of meadow architectural characteristics (shoot density, coverage and leaf length on the attenuation of orbital velocities and TKE. We aimed to improve our understanding of (1) how gaps modify the ecosystem 
engineering capacity of a shallow $P$. oceanica meadow and (2) the extent to which the modified hydrodynamics can be explained by the plant characteristics. Hydrodynamic parameters were measured within a $P$. oceanica meadow and within 3 different sized gaps. This paper complements research on habitat fragmentation, which showed that ecological processes in isolated habitat patches may differ substantially from those in larger, continuous habitats (Hovel \& Lipcius 2001, Fonseca et al. 2002, Borg et al. 2005).

\section{MATERIALS AND METHODS}

\section{Study site}

Hydrodynamic parameters were measured within a Posidonia oceanica meadow located in an approximately $0.5 \mathrm{~km}^{2}$ study site, Cala Montgó, in the northwest Mediterranean Sea $\left(42^{\circ} 6.4^{\prime} \mathrm{N}, 3^{\circ} 10.3^{\prime} \mathrm{E}\right)$, within in the Natural Park of Montgrí, Medes Islands and Baix Ter (code Natura 2000 ES5120016) (Fig. 1). The cala (beach) is a semi-enclosed bay exposed to the
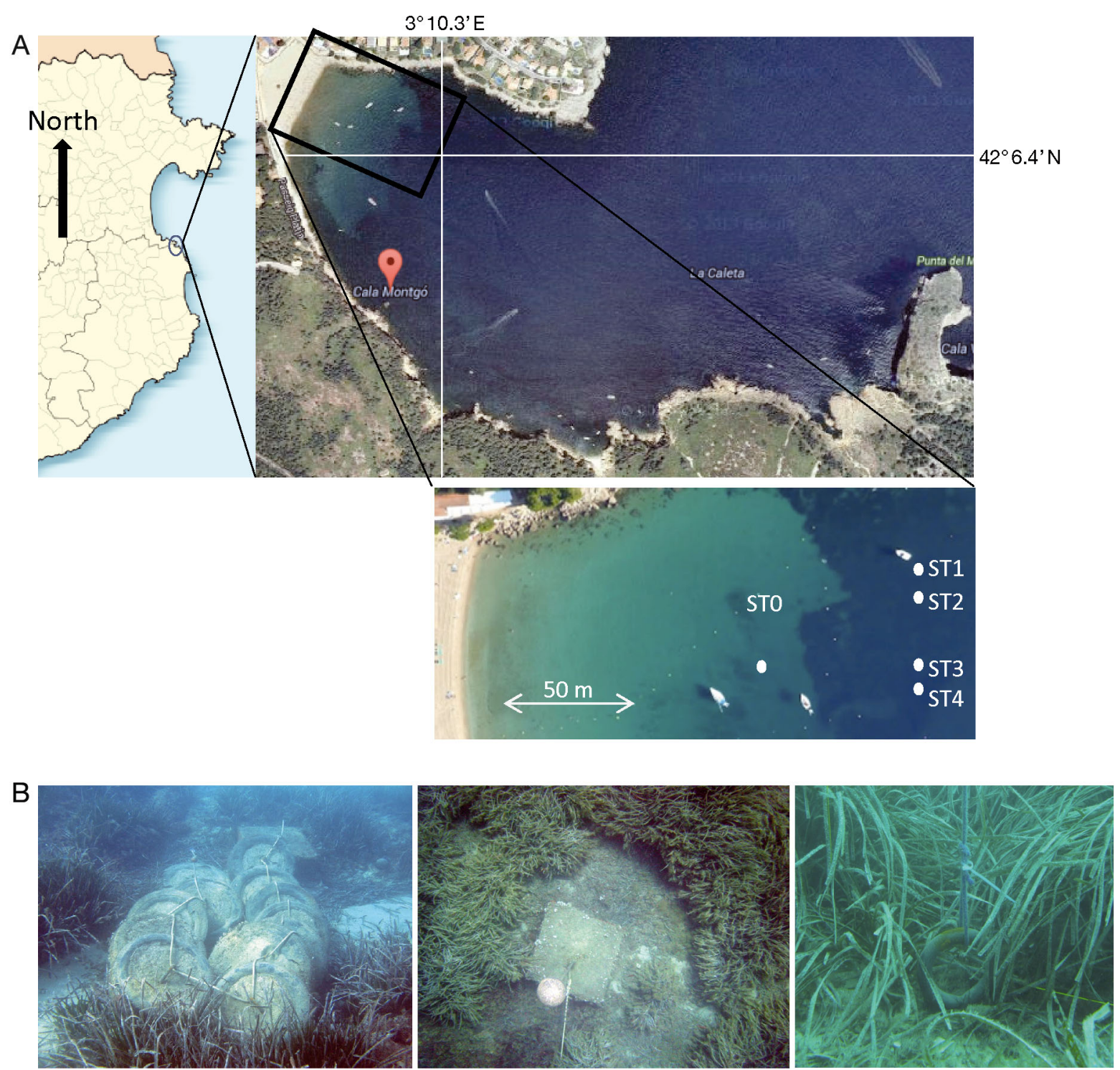

Fig. 1. Study sites located in Cala Montgó, Catalonia, Spain. (A) The 5 study stations (ST0, ST1, ST2, ST3 and ST4) within and outside the Posidonia oceanica bed are labeled on the aerial image. Coordinates at given in UTM 31N datum ETRS89. (B) Photographs of Stns ST2 (left, photograph taken at $1 \mathrm{~m}$ above the bottom) and ST3 (central, photograph taken at $3 \mathrm{~m}$ above the bottom) with the traditional moorings, and Stn ST2 (right, photograph taken at $1 \mathrm{~m}$ above the bottom) with the 'ecological' mooring. Left and central photographs were taken by Jordi Sànchez (SUBMON) and right photograph by Marianna Soler. The photographs of the bottom were taken between 6 and $8 \mathrm{~m}$ water depth 
incoming wind and waves from the southeast and east. Mild southeast winds prevail during most of the year, but storms arriving from the east along the Catalan coast contribute the most extreme wave stress in the study area due to the long, uninterrupted fetch from that direction.

The area has a gently sloping meadow of $P$. oceanica extending from 6 to 16 or $18 \mathrm{~m}$ water depth. It is a well preserved meadow which provides habitat for both Pinna nobilis and $P$. rudis. In Cala Montgó, an extensive field of 79 fixed moorings were detected by Sánchez et al. (2008) based on aerial imagery and divers' inspection. In Cala Montgó, $10 \%$ of these moorings are installed above rocky bottoms, 39\% over sandy bottoms and $47 \%$ within the $P$. oceanica meadow. Damage produced by the mooring chains dragging over the meadows denuded these areas of seagrasses, resulting in sandy patches which, in some cases, extend $2 \mathrm{~m}$ around the moorings (Sánchez et al. 2008). In 2012, as part of an extensive program to preserve the $P$. oceanica meadow in Cala Montgó, 6 traditional moorings were replaced by 'ecological' screw-based moorings, and provided an opportunity to compare the impact of gaps on meadow hydrodynamics.

A total of 5 field campaigns were conducted in June and October 2012, and in January, May and July 2013 to describe demographic characteristics (shoot density, coverage and leaf length) (see Table 2 for details). In addition, 7 campaigns were conducted to provide hydrodynamics characteristics (orbital velocity and TKE). These were conducted in June (2 different days), October (2 different days) and December 2012, and in July 2013 (2 different days). Photographs in Fig. 1B (left and central bottom) show 2 stations (ST2 and ST3, respectively) with the traditional moorings that were later removed, and Fig. 1B (right bottom) shows a close-up of the ecological mooring at the smallest gap (ST2) that was installed after removing the traditional mooring (Fig. 1B, left bottom photograph). Three elongated transversal gaps (perpendicular to the coast) that had been formed by previous moorings were chosen for monitoring (Stns ST2, ST3 and ST4; Table 1B) the hydrodynamics and demographic conditions of the nearby, uninjured meadow. The gaps were also categorized as being occupied by sand or dead mat (in the form of a mixture of dead leaves, rhizome and sediments) as the dead meadow could afford some degree of protection against flow- induced sediment movement. The gap stations were separated by distances larger than 5 times the gap width, and thus were considered replicates. Two additional stations were sampled: Stn ST0, which was dominated by bare sediment, and Stn ST1, which was situated within a seagrass canopy with no gaps within a distance of $15 \mathrm{~m}$ and was thus considered representative of a fully vegetated (i.e. undisturbed) meadow.

\section{Seagrass structural data}

Measurements of shoot density, coverage and leaf length were performed at the 4 vegetated stations (ST1, ST2, ST3 and ST4). Structural data concerning the percent cover and shoot density of $P$. oceanica were obtained by divers. Coverage was defined as the percentage of substrate covered by live P. oceanica. Percent cover was measured by the diver hovering $3 \mathrm{~m}$ above the bottom, holding at arm's length a $30 \times 30 \mathrm{~cm}$ transparent plastic sheet divided into nine $100 \mathrm{~cm}^{2}$ squares, and counting the number of squares occupied by $P$. oceanica (Leriche et al. 2006). Percent cover measurements were performed multiple times, at equally spaced distances at each station. At ST2, 4 percent cover measurements were made, 1 on each of the 4 sides of the gap. At ST3, 6 measurements were made, 2 across each of the longitudinal sides of the gap, and 1 across each of the width sides of the gap. At the largest gap, ST4, 10 measurements were made, 3 of them across each of the longitudinal sides of the gap, and 2 across each of the width sides of the gap. The distance between percent cover measurements was approximately $50 \mathrm{~cm}$. The percent cover in the gapped meadows (ST2, ST3 and ST4) were normalized to percent cover in the undisturbed meadow (ST1).

$P$. oceanica shoot density was measured following Vacchi et al. (2010), by counting shoots within a $40 \times$ $40 \mathrm{~cm}$ area subdivided into 4 sub-quadrats of $20 \times$ 
$20 \mathrm{~cm}$ for sub-meter spatial resolution, placed on the seagrass canopy. In fully vegetated Stn ST1, 8 replicates were performed while at Stns ST2, ST3 and ST4, 3, 5 and 7 replicates were performed, respectively. $P$. oceanica leaf lengths were measured to the nearest $\mathrm{mm}$ (Alcoverro et al. 1995), on 10 vertical shoots collected at each station (see Table 2). Surveys were repeated during each of 5 field campaigns which captured the seasonal variability of the structural characteristics of each station during (1) summer: 22 June 2012; (2) autumn: 5 October 2012; (3) winter: 30 January 2013; (4) spring: 20 May 2013 and (5) summer: 1 July 2013. Data on shoot density, cover and leaf length was checked for normality by using the Shapiro-Wilk test with the SPSS software package (SPSS Statistics, IBM). In the case of non-normally distributed data, a data transformation was first applied following Sokal \& Rohlf (1995) before performing a 2-way ANOVA without replication on the structural data.

\section{Hydrodynamic data}

Hydrodynamic data also were collected during 7 field campaigns that corresponded to seasonal sampling periods for the canopy structural data: (1) summer: 21 and 29 June 2012; (2) autumn: 24 and 26 October 2012; (3) winter: 7 December 2012 and (4) summer: 2 and 9 July 2013. During the hydrodynamic campaigns, water velocities and KE within the gaps under relatively calm conditions were recorded to determine any inherent seasonal variability in hydrodynamics associated with seasonal change of the canopy structure (note that no acoustic Doppler velocity [ADV] data were collected in spring 2012). Wind data were obtained from a meteorological station in the city of L'Estartit, located $6.2 \mathrm{~km}$ south of Cala Montgó; wind velocities did not exceed $3 \mathrm{~m} \mathrm{~s}^{-1}$ during the field campaigns. We note, however, that on 31 October 2012, between field campaigns, an easterly storm occurred lasting $22 \mathrm{~h}$ with significant wave heights between 3 and $6 \mathrm{~m}$. The occurrence of this extreme event during our evaluation period is noted as it can be used to explain some observed seascape-scale differences.

High-frequency $u$ (east-west), $v$ (north-south) and $w$ (vertical) velocity components were measured at 2 heights above the bottom at each station, using 2 acoustic Doppler current meters mounted vertically in line on a stainless steel bar. One Doppler current meter (ADV Vector, Nortek) was positioned facing down so that the sampling volume was $25 \mathrm{~cm}$ above the bottom, and the second current meter (ADV
Ocean, Sontek) was positioned facing up so that the sampling volume was $60 \mathrm{~cm}$ above the bottom. At Stn ST1, the apparent canopy height during the spring and summer periods was $\sim 0.45 \mathrm{~m}(10 \%$ shorter than the leaf length) while in winter it was $0.20 \mathrm{~m}$; almost all leaves had undergone seasonal dehiscence from the individual shoots. To measure velocities within the meadow at ST1, 4 to 7 plants were removed to prevent leaves from blocking the sampling volume (Neumeier \& Amos 2006).

At each station, flow velocity was measured over $10 \mathrm{~min}$ at $25 \mathrm{~Hz}$ (ADV Sontek) and $32 \mathrm{~Hz}$ (ADV Nortek) sampling frequencies, after which the instruments were moved by divers to the next station. After removing spikes from the velocity time-series, the axes of the instantaneous velocities were rotated parallel and perpendicular to the shore. In addition, an acoustic Doppler current profiler (ADCP Sentinel, Teledyne RDI) was deployed at the bare sediment station, ST0 (Fig. 1, Table 1), $5 \mathrm{~m}$ above bottom and positioned facing down. It recorded $3 \mathrm{D}$ velocities at a frequency of $2 \mathrm{~Hz}$, in beams of $20 \mathrm{~cm}$ width, during each field campaign. Measurements at ST0 were analysed to extract wave velocities and wave direction during the field campaigns. The variation of mean velocities and mean directions at ST0 and at $1.5 \mathrm{~m}$ above the bottom over the measurement time between stations was always below $10 \%$, allowing comparison of results between stations.

ADV measurements were collected across 5 points at each gap station (Stns ST2 to ST4): at the meadow-gap interface and at 4 different distances perpendicular to the interface ( $y$-axis). The interface was set at $y=0$, with $y$ being positive within the gap and negative within the meadow. At all 3 sites, the largest $y$-value was approximately at the center of the gap (Fig. 2). At ST4, measurements were taken at $y=-2$, $-1,0,+1$ and $+2 \mathrm{~m}$. At ST3, measurements were taken at $y=-1,-0.5,0,+0.5$ and $+1 \mathrm{~m}$. At ST2, measurements were taken at $y=-0.5,-0.25,0,+0.25$ and $+0.5 \mathrm{~m}$. At ST4, transects were repeated twice to encompass longitudinal variations in the hydrodynamic conditions. A 2-way ANOVA without replication was also applied to the wave velocity data at the middle of the gap for the different stations and for different surveys. Levene's test was used to test data homogeneity and a log-normal transformation was accordingly applied.

The resolution and accuracy of the velocity measurements were 0.01 and $0.1 \mathrm{~cm} \mathrm{~s}^{-1}$ for the NorteK $A D V$, and 0.1 and $0.5 \mathrm{~cm} \mathrm{~s}^{-1}$ for the Sontek ADV. Wave data were filtered to remove waves not approaching perpendicular to the beach (Infantes et 


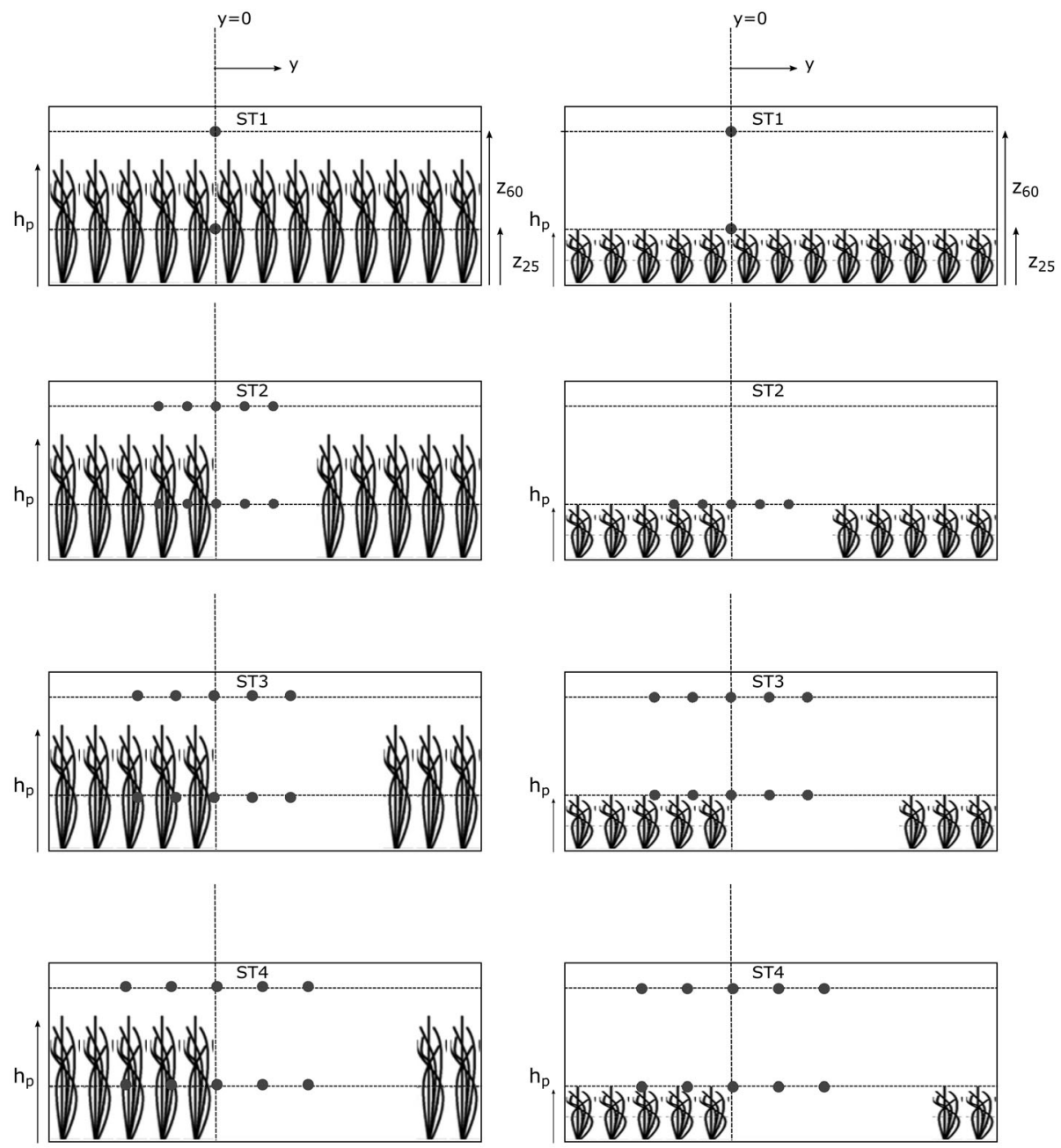

Fig. 2. Field campaign characteristics at the gap stations in the Posidonia oceanica meadow. Vertical axis measurements were done at heights of 25 and $60 \mathrm{~cm}$ (i.e. $z_{25}$ and $z_{60}$ ). Transversal $y$ direction measurements were done at 5 positions indicated by grey circles: 2 on the gap, at the edge-meadow interface and 2 in the adjacent meadow. Stn ST2 was the lowest width gap while ST4 was the largest. Left panels refer to measurements carried out under standard conditions, right panels refer to a canopy after a storm in which leaf length is largely reduced. Under such conditions the measurements at $25 \mathrm{~cm}$ (i.e. $z_{25}$ ) are above the canopy since the height of the canopy (hp) was around $20 \mathrm{~cm}$

al. 2012). Within the duration of each campaign $(\sim 5 \mathrm{~h})$, neither the wind nor wave velocities changed substantially $(<10 \%)$. The instantaneous velocities $(u, v, w)$ were decomposed into mean $\left(U_{\mathrm{c}}, V_{\mathrm{c}}, W_{\mathrm{c}}\right)$, orbital $\left(U_{\mathrm{w}}, V_{\mathrm{w}}, W_{\mathrm{w}}\right)$ and turbulent $\left(u^{\prime}, v^{\prime}, w^{\prime}\right)$ velocities following the method described by Pujol et al. (2013a). TKE was then calculated as:

$$
\mathrm{TKE}=0.5\left(u^{\prime 2}+v^{\prime 2}+w^{\prime 2}\right)
$$

To quantify changes in the longitudinal component of the wave-induced flow, as potentially influenced by the gap dimensions and structural characteristics of lateral meadows, the velocities at each station sampling point $\left(U_{\mathrm{w}}\right)$ were normalized by the velocities measured at the center of largest gap, $U_{\mathrm{w} 0}$, at the same elevations, $z=0.25$ and $z=0.60 \mathrm{~m}$ (Fig. 2). We considered the wave characteristics to be approximately the same at the gap stations since the distance of each gap to the upper canopy height was the same. The resulting dimensionless parameter:

$$
\alpha=U_{\mathrm{w}} / U_{\mathrm{w} 0}
$$

provided the change in the longitudinal component of the wave-induced flow induced by either the meadow (Lowe et al. 2005, Manca et al. 2012) or the gap, and can be considered an indicator of flow attenuation. The TKE at each station sampling point was normalized by the TKE at the center of the largest gap, $\mathrm{TKE}_{0}$, at the same elevations, resulting in another dimensionless parameter:

$$
\beta=\mathrm{TKE} / \mathrm{TKE}_{0}
$$




\section{RESULTS}

\section{Seagrass bed architectural measurements}

Mean shoot densities and percent cover were higher at the full canopy station (Stn ST1; Table 2) and lower at the vegetated margins of Stns ST2, ST3 and ST4. The mean lateral seagrass shoot density, the lateral percent cover and the leaf length of the largest gap area (gap Stn ST4; Table 1) were 12, 16 and $20 \%$, respectively, lower than the shoot density, coverage and leaf length at the full canopy Stn ST1 (Table 2).

ANOVA showed that significant differences occurred in shoot density across gap stations, whereas smaller differences occurred across time. In contrast, there were significant differences in percent cover

Table 2. Posidonia oceanica morphometrics, including shoot density, percent cover and leaf length for Cala Montgó. Values represent means $\pm \mathrm{SD}$

\begin{tabular}{|c|c|c|c|c|}
\hline Stn & $\begin{array}{c}\text { Day } \\
\text { (dd/mm/ } \\
\text { уууу) }\end{array}$ & $\begin{array}{c}\text { Density } \\
\text { (shoots } \\
\mathrm{m}^{-2} \text { ) }\end{array}$ & $\begin{array}{c}\text { Percent } \\
\text { cover } \\
(\%)\end{array}$ & $\begin{array}{l}\text { Leaf } \\
\text { length } \\
(\mathrm{m})\end{array}$ \\
\hline ST1 & $\begin{array}{l}22 / 06 / 2012 \\
05 / 10 / 2012 \\
30 / 01 / 2013 \\
20 / 05 / 2013 \\
01 / 07 / 2013\end{array}$ & $\begin{array}{l}286 \pm 41 \\
288 \pm 16 \\
311 \pm 19 \\
295 \pm 23 \\
290 \pm 32\end{array}$ & $\begin{array}{l}45.5 \pm 6.6 \\
43.8 \pm 5.0 \\
20.4 \pm 5.5 \\
58.4 \pm 8.3 \\
55.4 \pm 7.8\end{array}$ & $\begin{array}{l}0.51 \pm 0.06 \\
0.40 \pm 0.05 \\
0.21 \pm 0.09 \\
0.52 \pm 0.04 \\
0.49 \pm 0.05\end{array}$ \\
\hline ST2 & $\begin{array}{l}22 / 06 / 2012 \\
05 / 10 / 2012 \\
30 / 01 / 2013 \\
20 / 05 / 2013 \\
01 / 07 / 2013\end{array}$ & $\begin{array}{l}285 \pm 39 \\
274 \pm 16 \\
298 \pm 20 \\
306 \pm 26 \\
303 \pm 36\end{array}$ & $\begin{array}{l}41.8 \pm 6.6 \\
38.5 \pm 5.6 \\
17.6 \pm 5.0 \\
54.9 \pm 7.9 \\
51.6 \pm 7.8\end{array}$ & $\begin{array}{l}0.50 \pm 0.05 \\
0.38 \pm 0.06 \\
0.20 \pm 0.09 \\
0.46 \pm 0.05 \\
0.49 \pm 0.04\end{array}$ \\
\hline ST3 & $\begin{array}{l}22 / 06 / 2012 \\
05 / 10 / 2012 \\
30 / 01 / 2013 \\
20 / 05 / 2013 \\
01 / 07 / 2013\end{array}$ & $\begin{array}{l}257 \pm 37 \\
258 \pm 18 \\
289 \pm 20 \\
281 \pm 22 \\
282 \pm 36\end{array}$ & $\begin{array}{l}48.4 \pm 3.6 \\
45.3 \pm 4.5 \\
21.1 \pm 5.4 \\
53.1 \pm 6.9 \\
49.8 \pm 6.8\end{array}$ & $\begin{array}{l}0.44 \pm 0.06 \\
0.36 \pm 0.06 \\
0.17 \pm 0.09 \\
0.44 \pm 0.04 \\
0.47 \pm 0.05\end{array}$ \\
\hline ST4 & $\begin{array}{l}22 / 06 / 2012 \\
05 / 10 / 2012 \\
30 / 01 / 2013 \\
20 / 05 / 2013 \\
01 / 07 / 2013\end{array}$ & $\begin{array}{l}231 \pm 40 \\
245 \pm 17 \\
263 \pm 20 \\
280 \pm 24 \\
277 \pm 38\end{array}$ & $\begin{array}{l}40.6 \pm 4.3 \\
36.0 \pm 4.6 \\
15.8 \pm 6.2 \\
50.0 \pm 6.7 \\
45.9 \pm 6.9\end{array}$ & $\begin{array}{l}0.42 \pm 0.07 \\
0.31 \pm 0.07 \\
0.15 \pm 0.10 \\
0.40 \pm 0.06 \\
0.42 \pm 0.06\end{array}$ \\
\hline
\end{tabular}

and leaf length across time, but smaller across stations (Table 3). Both mean percent cover and mean leaf length were $60 \%$ lower at the end of January compared to the highest values measured during the July campaign.

The ratio between the percent cover at each gap station and at the full canopy increased between June 2012 and February 2013 for all stations and decreased in summer 2013 (Fig. 3). In spring and summer 2013, percent cover at fully vegetated Stn ST1 increased more than the percent cover at Stns ST2, ST3 and ST4, therefore the ratio of $\mathrm{ST}_{i} / \mathrm{ST} 1$ decreased during the summer 2013 campaigns. Furthermore, stations with larger gap dimensions presented lower percent cover ratios than stations with smaller gaps (Fig. 3), indicating that plants around smaller gaps were structured more like the fully vegetated site than those with larger gaps.

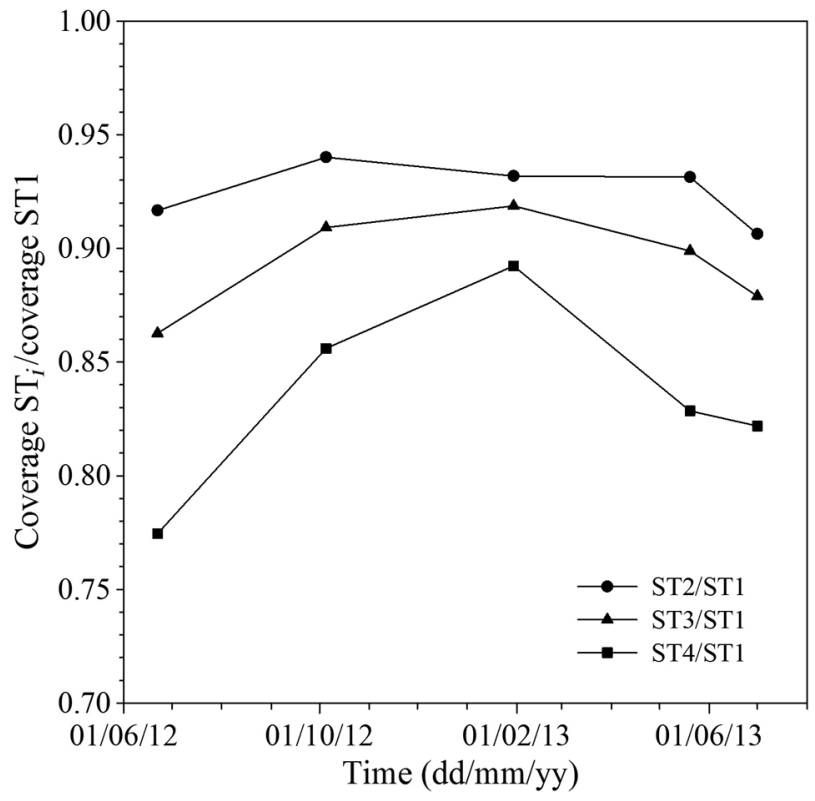

Fig. 3. Ratio between percent cover of Posidonia oceanica at each gap station $\left(\mathrm{ST}_{i}\right)$ and full canopy Stn $\mathrm{ST} 1$ during the study period

Table 3. Two-way ANOVA statistics for Posidonia oceanica shoot density, percent cover and leaf length, as well as the transformation applied to achieve data homogenization

\begin{tabular}{|c|c|c|c|c|c|c|c|c|c|c|}
\hline \multirow{2}{*}{$\begin{array}{l}\text { Source of } \\
\text { variation }\end{array}$} & \multirow[t]{2}{*}{ df } & \multicolumn{3}{|c|}{ Shoot density -} & \multicolumn{3}{|c|}{ - Percent cover } & \multicolumn{3}{|c|}{ - Leaf length- } \\
\hline & & MS & $F$ & $\mathrm{p}$ & MS & $F$ & $\mathrm{p}$ & MS & F & $\mathrm{p}$ \\
\hline Station & 3 & 0.0035 & 16.11 & $<0.01$ & 0.0038 & 7.18 & $<0.01$ & 0.00068 & 45.3 & $<0.01$ \\
\hline Date & 4 & 0.002 & 8.08 & $<0.01$ & 0.041 & 78.46 & $<0.01$ & 0.0065 & 427.44 & $<0.01$ \\
\hline Transformation & & $\log (x+$ & & & $\operatorname{Arcsin}[$ & $\left./(100)^{2}\right]$ & & $\log (x+$ & & \\
\hline
\end{tabular}




\section{Wave field and TKE in the gaps}

Significant differences (2-way ANOVA, p < 0.01) were found for wave velocities at the center of the gaps not only between dates but also between stations, showing the heterogeneous distribution of hydrodynamics due to the seagrass architecture at each station.

Both $\alpha$ and $\beta$ varied with distance to the meadowgap interface as well as between vertical heights and time of the year (Figs. $4 \& 5) . \alpha_{25}\left(\alpha_{60}\right)$ and $\beta_{25}\left(\beta_{60}\right)$ are the values at $25 \mathrm{~cm}(60 \mathrm{~cm})$ above the bottom, were velocities were measured.
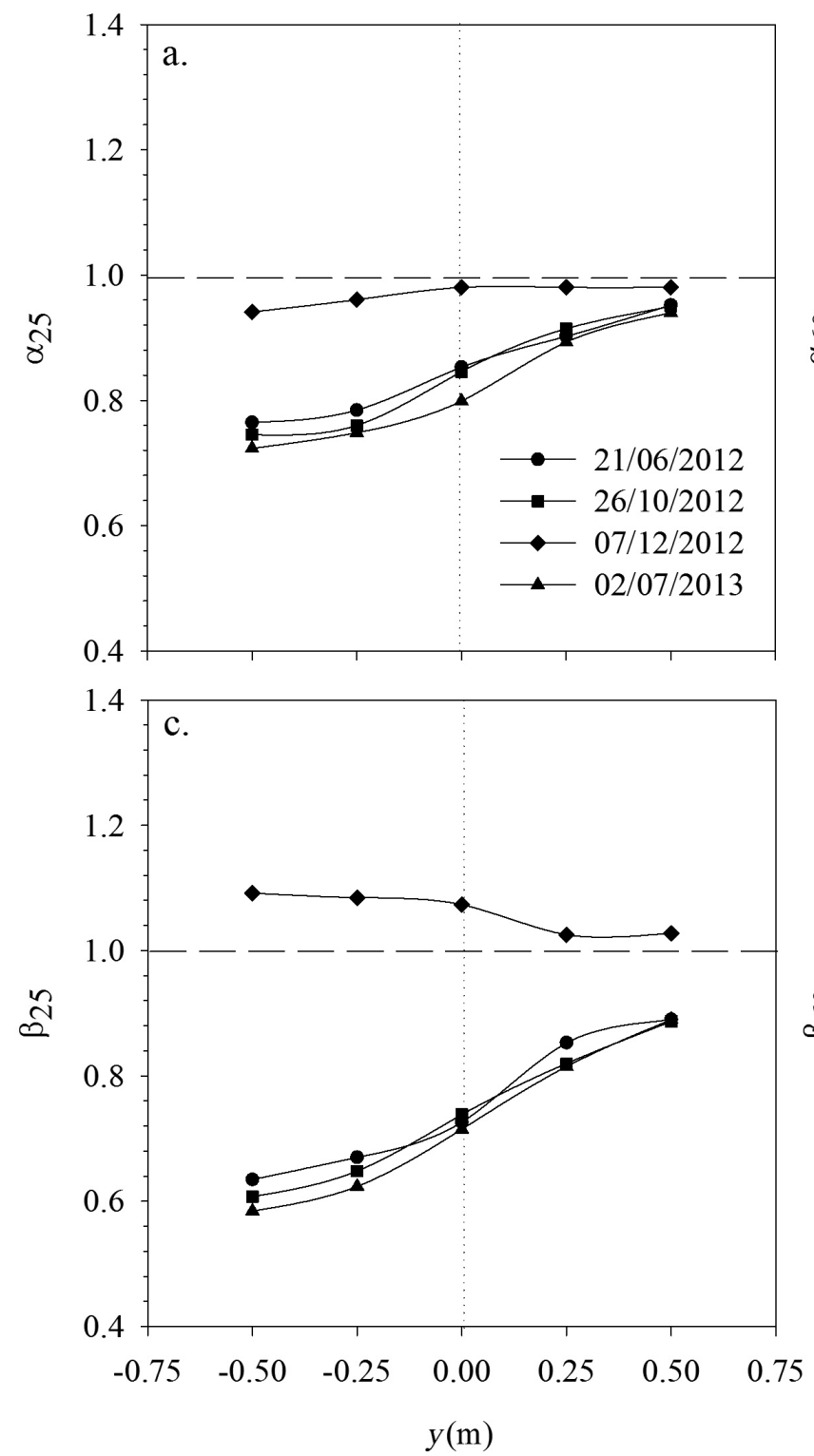

During the June 2012, October 2012 and July 2013 campaigns within the lateral vegetation of the smallest gap station (Stn ST2), at $z=25 \mathrm{~cm}$, mean wave velocities were attenuated by $26 \%$ (as indicated by $\alpha_{25}$ at $y=-0.5 \mathrm{~m}$ ). In contrast, in the center of the gap at $y=0.5 \mathrm{~m}$, wave attenuation was only $8 \%$ (Fig. 4a). Within the lateral vegetation at $y=-0.5 \mathrm{~m}$, and above the canopy at $z=60 \mathrm{~cm}$, mean wave velocities were attenuated by $10 \%$, compared to the $4 \%$ attenuation in the gap at $y=0.5 \mathrm{~m}$ (Fig. 4b). During the December 2012 campaign, $\alpha_{25}$ and $\alpha_{60}$ were greater than during the June 2012, October 2012 and July 2013 campaigns (Fig. $4 \mathrm{a}, \mathrm{b}$ ). The higher $\alpha_{25}$ and $\alpha_{60}$ values in
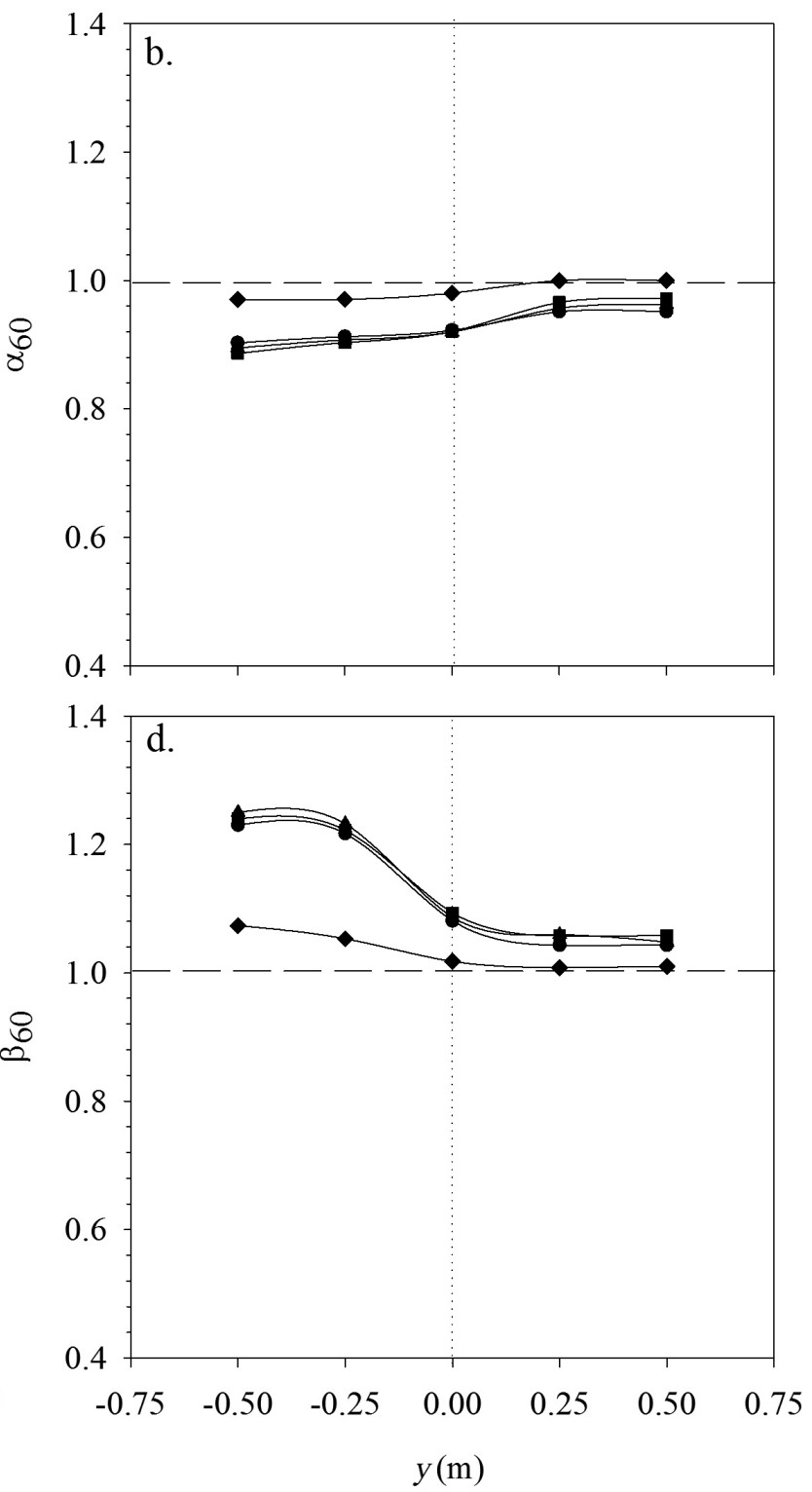

Fig. 4. Transversal flow attenuation parameter $\alpha$ (see Eq. 2) at gap Stn ST2 (lowest area) at height (a) $z=25 \mathrm{~cm}\left(\alpha_{25}\right)$ and (b) $z=$ $60 \mathrm{~cm}\left(\alpha_{60}\right)$, and transversal turbulent kinetic energy attenuation parameter $\beta$ (see Eq. 3) at Stn ST2 at height (c) $z=25 \mathrm{~cm}\left(\beta_{25}\right)$ and (d) $z=60 \mathrm{~cm}\left(\beta_{60}\right)$ for June, October, December and July campaigns 

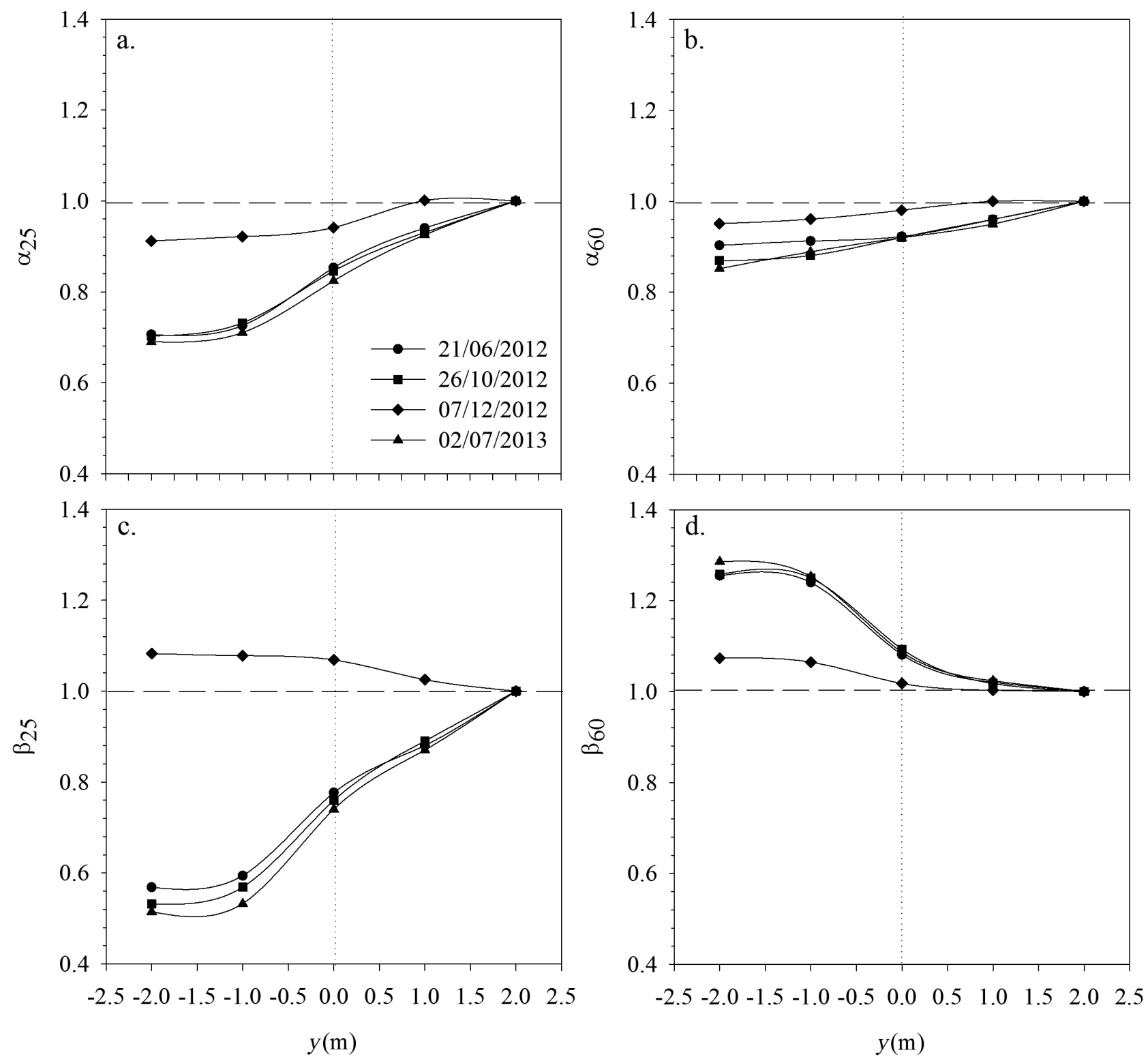

Fig. 5. Transversal flow attenuation parameter $\alpha$ (see Eq. 2) at gap Stn ST4 (largest area) at height (a) $z=25 \mathrm{~cm}\left(\alpha_{25}\right)$ and (b) $z=$ $60 \mathrm{~cm}\left(\alpha_{60}\right)$, and transversal turbulent kinetic energy attenuation parameter $\beta$ (see Eq. 3) at Stn ST4 at height (c) $z=25 \mathrm{~cm}\left(\beta_{25}\right)$ and (d) $z=60 \mathrm{~cm}\left(\beta_{60}\right)$ for June, October, December and July campaigns

December 2012 may have been the result of a storm at the end of October 2012 during which leaf length was reduced, so that $\alpha_{25}$ in December 2012 was considered to more closely reflect the wave attenuation at the top rather than within the canopy.

During the June 2012, October 2012 and July 2013 campaigns at Stn ST2, $\beta_{25}$ and $\beta_{60}$ were similar (Fig. $4 \mathrm{c}, \mathrm{d}$ ). TKE at $y=-0.5 \mathrm{~m}$ inside the lateral vegetation was $39 \%$, while at the center of the gap at $y=$ $0.5 \mathrm{~m}$, it was only $11 \%$ (Fig. 4c). At $z=60 \mathrm{~cm}$, during the summer and autumn months, the TKE at $y=-0.5 \mathrm{~m}$ above the lateral vegetation was $24 \%$ greater than the
TKE at the center of the largest gap while at the center of the gap, at $y=0.5 \mathrm{~m}$, TKE was only $5 \%$ larger than TKE at the center of the largest gap (Fig. 4d). However, during the December campaign, both $\beta_{25}$ and $\beta_{60}$ were $>1$ all along the transect (Fig. $4 \mathrm{c}, \mathrm{d}$ ).

The $\alpha$ and $\beta$ parameters for the largest gap station (Stn ST4; Table 1) within the lateral vegetation and within the gap were also dependent on the distance to the meadow-gap interface as well as on vertical heights and time of the year. Greatest differences in the ST4 gap were found within the lateral vegetation; at $y=-2.0 \mathrm{~m}, \alpha_{25}$ was 0.70 (Fig. 5a) and $\beta_{25}$ varied 


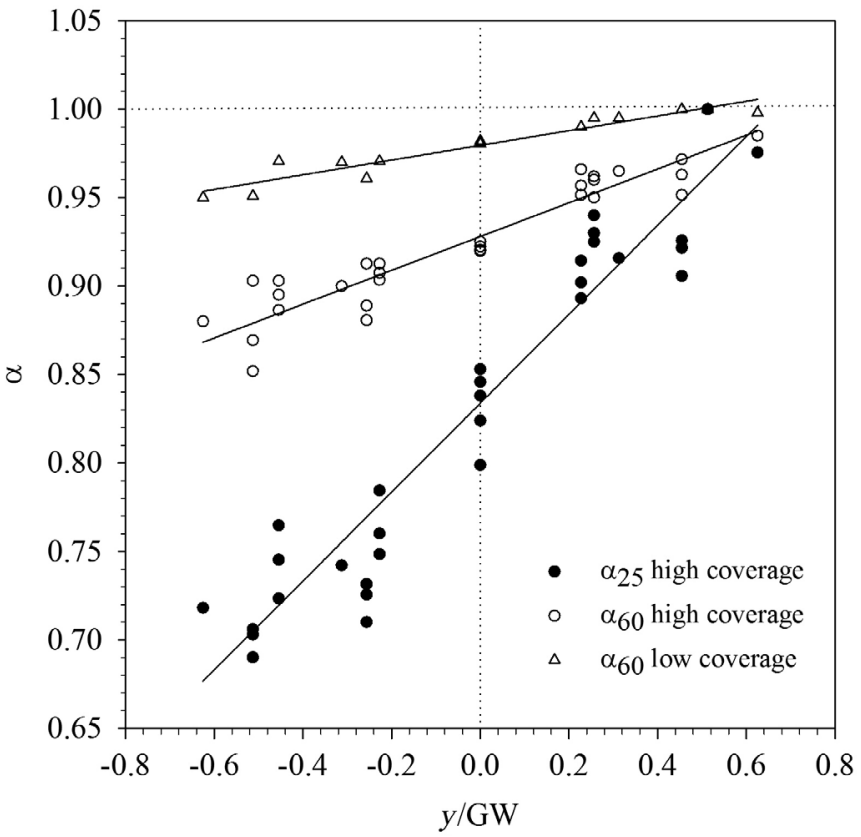

Fig. 6. Wave attenuation ( $\alpha$, see Eq. 2 ) at heights $z=25$ and $60 \mathrm{~cm}$ versus $y / \mathrm{GW}$, where GW is the gap width, for gap Stns ST2, ST3 and ST4

between 0.51 and 0.57 (Fig. 5c), indicating that well inside the lateral vegetation the reduction of orbital velocity can be up to $30 \%$ while the TKE can be reduced to a mean of $46 \%$. Above the canopy, $\alpha_{60}$ and $\beta_{60}$ were close to that found at Stn ST2.

Both $\alpha_{25}$ and $\beta_{25}$ in the lateral vegetated area and at both Stns ST2 (Fig. 4a,c) and ST4 (Fig. 5a,c) were lowest during the July campaign, presumably a period of peak growth. In contrast, $\beta_{60}$ was greatest in the July campaign (Figs. $4 \mathrm{~d} \& 5 \mathrm{~d}$ ). These characteristics coincided with greater percent cover during summer (peak growth) at both sites (Table 2).

For all stations and in all field surveys, $\alpha$ was always below 1 within both the vegetation and the gap, with the lowest $\alpha_{25}$ occurring during high percent cover and the highest $\alpha_{60}$ occurring during low percent cover (Fig. 6). $\alpha$ presented a linear relationship with $y / G W$, where GW is the gap width, with a positive slope in all cases. The highest slope $(\mathrm{m}=$ $0.261, R^{2}=0.927,99 \%$ significance) was for $\alpha_{25}$ with high percent cover. $\alpha_{60}$ with high percent cover and $\alpha_{60}$ with low percent cover also presented a linear trend with $y / G W$, with slopes $\mathrm{m}=0.095\left(\mathrm{R}^{2}=0.881\right.$, $99 \%$ significance $)$ and $m=0.016\left(R^{2}=0.833,99 \%\right.$ significance) respectively. All 3 trend lines reached a value of 1 when $y / G W \approx 0.6$, indicating that attenuation had stabilized.

$\beta$ also varied linearly with $y /$ GW (Fig. 7); however, contrary to what was found for $\alpha$, the slope for $\beta_{60}$ was

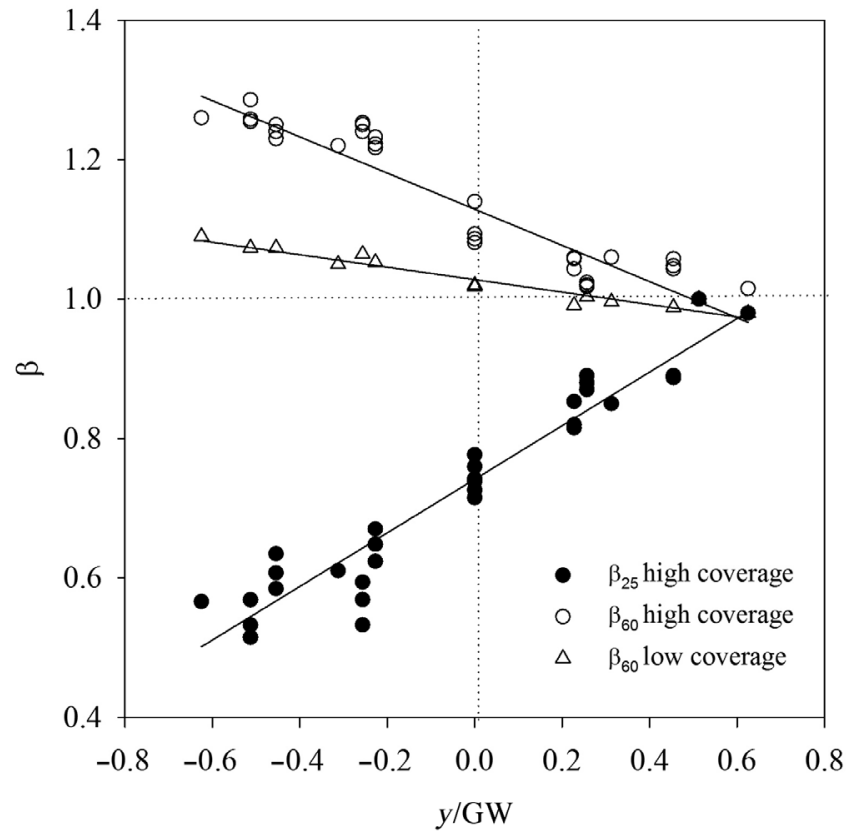

Fig. 7. Turbulent kinetic energy attenuation ( $\beta$, see Eq. 3 ) at different heights versus $y / G W$, where GW is the gap width, for gap Stns ST2, ST3 and ST4

negative, indicating that the higher the $y / \mathrm{GW}$, the smaller the $\beta_{60}$. The slope for $\beta_{60}$ with high percent cover was higher $\left(\mathrm{m}=-0.260, \mathrm{R}^{2}=0.869,99 \%\right.$ confidence) than that for the low percent cover case $(\mathrm{m}=$ $-0.030, R^{2}=0.696,99 \%$ confidence). In contrast, $\beta_{25}$ had a positive slope of $m=0.384\left(R^{2}=0.921,99 \%\right.$ confidence). $\beta_{60}$ and $\beta_{25}$ both reached a value close to 1 within the gap at $y / G W \approx 0.6$ (Fig. 7).

\section{DISCUSSION}

In this field-based investigation of seagrass meadow fragmentation and sandy gaps, we found that both structural characteristics of the meadow and the size of the longitudinal gap determined the capacity of the vegetation to attenuate both the wave velocities and the TKE. Thus, gap size, architectural characteristics and temporal variability must be considered when assessing both the influence of seagrass habitat on wave hydrodynamics and the severity of anthropogenically created gaps in seagrass canopies. Seagrass meadows modify the benthic boundary layer, which manifests in changes in mean velocities, orbital velocities and turbulence (Granata et al. 2001, Infantes et al. 2012, Ros et al. 2014). This modification is generally understood to be moderated by the architectural characteristics of the meadow (both shoot density and number of leaves per shoot) and the plants 
(shoot biomass, leaf length, leaf width, blade stiffness) (Borg et al. 2005, Peralta et al. 2008, Paul et al. 2012). The presence of gaps within a canopy reduces the capacity of meadows to attenuate waves and turbulence (Boudouresque et al. 2012).

Differences in leaf length and percent cover in the vegetated area situated adjacent to the gap can be driven by changes in light climate, water temperature and seasonal hydrodynamic conditions. While light climate and temperature were not measured in this study, we recognize that the change in seagrass structure among campaigns could markedly influence the observed hydrodynamic conditions in the vicinity of the seagrass bed. El Allaoui et al. (2016) highlighted the increase in the mixing level that occurred in a patchy canopy compared with a canopy without gaps. An increase in mixing can cause an increase in sediment resuspension, which can result in a reduction in water clarity, threatening seagrass growth (Lawson et al. 2007, van der Heide et al. 2007, Carr et al. 2012).

Gaps of different spatial characteristics within the Posidonia oceanica meadow of Cala Montgó created situations in which seagrass bed margins were exposed to different levels of KE. The larger the gap width, the lower the percent cover of the lateral vegetation, indicating that the gap exerted some influence on the architectural characteristics of the nearby vegetation. Tanner (2005) commented that the ecological processes associated with canopy edges may differ from those in interior habitats. In his study, he showed that total seagrass biomass tended to increase smoothly with distance from the edge rather than abruptly from zero to the maximum density. Tanner (2005) also found that most of the change occurred within 0.5 to $1 \mathrm{~m}$ from the edge of the seagrass canopy, coinciding with the hydrodynamic results from the present study. These results highlight differences between edge and canopy habitat interiors, making it possible to determine the extent of the modification as a function of the canopy architecture. Within the lateral vegetation, the lower the percent cover of plants, the lower the capacity of the vegetation to reduce waves and TKE. Therefore, we expect a negative feedback whereby the lateral vegetation is increasingly vulnerable through the reduction of wave attenuation capacity. This negative feedback may be exacerbated when mooring occurs in meadows with weak meadow compactness and low shoot density (Milazzo et al. 2004, Demers et al. 2013). Therefore canopies fragmented with large gaps will likely be more vulnerable (i.e. less resilient) and allow greater penetration of waves and currents into the canopy, which will enhance sediment resuspension and favor exchange between the meadow and the gap. These conclusions support those of Gacia \& Duarte (2001), while Hendriks et al. (2008), El Allaoui et al. (2015) and El Allaoui et al. (2016) reported the buffering of sediment resuspension by $P$. oceanica meadows. El Allaoui et al. (2016) found that canopies with large gaps had a higher mixing level than canopies with small gaps, despite both canopies having the same total gap area.

After a major storm with predominantly easterly winds, the meadow showed dramatic changes, specifically in percent cover and leaf length, both of which modified the sheltering capacity of the canopy adjacent to the gaps (although shoot density did not change). It is likely that the variability of the weather conditions in the Mediterranean produce both temporal and spatial heterogeneities within the meadow in a complicated association with anchor damage. Manca et al. (2012) suggested that $P$. oceanica canopies significantly protect coastal areas from wave erosion during storms and promote sediment stabilization in the nearshore zone. Similarly, Sanchez-Vidal et al. (2012) showed that extreme coastal storms in the western Mediterranean Sea rapidly impact the coastal ecosystem; one of the most extreme coastal storms initiated the movement of large amounts of coarse shelf sediment that buried benthic communities.

In the present study, the October 2012 storm resulted in a reduction of the percent cover and leaf length at all gap stations. Also, the ratio between percent cover at the gap stations (Stns ST3 and ST4) and percent cover at the meadow station was highest after the storm. Our results show that although moderately energetic storms may alter the length of the plants, they may not affect the density of the canopy. Canopy percent cover was lower 3 mo after the passage of the storm, but was greater after 7 and 9 mo. The greater increase in percent cover for the (lateral) vegetation was observed nearest the smallest gaps, indicating that canopies might respond to storms, not only by recovering at a plant scale but also at a canopy scale. The percent cover dependence on season (by changing leaf length) might represent a strategy to increase the sheltering and protection of edges or boundaries, but this requires experimental investigation. Alternatively, the increase in percent cover at the edge of the canopy may be the result of a higher nutrient uptake by the plants due to increased mixing levels (Thomas \& Cornelisen 2003, Ricart et al. 2015). Both the self-regulation mechanisms and biogeomorphological adaptations might explain the 
patterns and dynamics observed in seagrass meadows (van Katwijk et al. 2010, Möller et al. 2011).

Gaps with widths less than 2 leaf lengths of the adjacent vegetation may still cause a reduction in waves and turbulence, although to a lesser extent than fully vegetated meadows. Longitudinal gaps (transversal to the coast) with widths larger than twice the leaf length were shown to be vulnerable to full penetration of the wave field. It is suggested that gaps of sufficient size could in turn exceed the capacity of the meadow to dampen water motion and reduce meadow resilience. These results support suggestions by Montefalcone et al. (2010) and Ondiviela et al. (2014) that the equilibrium between natural disturbance regimes and canopies may be altered when human activities impose an extra stress, in which case vegetative growth may no longer be able to compensate for meadow fragmentation.

Acknowledgements. C.O. was supported by a Study Leave Grant from The University of Western Australia. We greatly thank the Fundación Biodiversidad for funding support through project FB-AIN2011B.

\section{LITERATURE CITED}

Abadie A, Gobert S, Bonacorsi M, Lejeune P, Pergent G, Pergent-Martini C (2015) Marine space ecology and seagrasses. Does patch type matter in Posidonia oceanica seascapes? Ecol Indic 57:435-446

Abadie A, Lejeune P, Pergent G, Gobert S (2016) From mechanical to chemical impact of anchoring in seagrasses: the premises of anthropogenic patch generation in Posidonia oceanica meadows. Mar Pollut Bull 109: 61-71

Alcoverro T, Duarte CM, Romero J (1995) Annual growth dynamics of Posidonia oceanica: contribution of largescale versus local factors to seasonality. Mar Ecol Prog Ser 120:203-210

Blanchette CA (1997) Size and survival of intertidal plants in response to wave action: a case study with Fucus gardneri. Ecology 78:1563-1578

Borg JA, Attrill MJ, Rowden AA, Schembri PJ, Jones MB (2005) Architectural characteristics of two bed types of the seagrass Posidonia oceanica over different spatial scales. Estuar Coast Shelf Sci 62:667-678

Boudouresque CF, Thommeret J, Thommeret Y (1980) Sur la découverte d'un bioconcrétionnement fossile intercalé dans l'herbier à Posidonia oceanica de la Baie de Calvi (Corse). Journées d'étude sur la systématique et la biogéographie de la mer Méditerranée, Cagliari. CIESM, Monaco, p 139-142

Boudouresque CF, Bernard G, Bonhomme P, Charbonnel E and others (2012) Protection and conservation of Posidonia oceanica meadows. RAMOGE and RAC/SPA Publishers, Tunis

Cabaço S, Santos R, Duarte CM (2008) The impact of sediment burial and erosion on seagrasses: a review. Estuar Coast Shelf Sci 79:354-366
Carr JA, D'Odorico P, McGlathery KJ, Wiberg PL (2012) Stability and resilience of seagrass meadows to seasonal and interannual dynamics and environmental stress. J Geophys Res 117:G01007

*Demers MCA, Davis AR, Knott NA (2013) A comparison of the impact of seagrass-friendly boat mooring systems on Posidonia australis. Mar Environ Res 83:54-62

* Duarte CM (1991) Seagrass depth limits. Aquat Bot 40: 363-377

*El Allaoui N, Serra T, Soler M, Colomer J, Pujol D, Oldham C (2015) Modified hydrodynamics in canopies with longitudinal gaps exposed to oscillatory flow. J Hydrol (Amst) 531:840-849

El Allaoui N, Serra T, Colomer J, Soler M, Casamitjana X, Oldham C (2016) Interactions between fragmented seagrass canopies and the local hydrodynamics. PLOS ONE 11:e0156264

Fonseca MS, Callahan JA (1992) A preliminary evaluation of wave attenuation by four species of seagrass. Estuar Coast Shelf Sci 29:501-507

Fonseca MS, Fisher JS, Zieman JC, Thayer GW (1982) Influence of the seagrass, Zostera marina L., in current flow. Estuar Coast Shelf Sci 15:351-364

Fonseca M, Whitfield PE, Kelly NM, Bell SS (2002) Modeling seagrass landscape pattern and associated ecological attributes. Ecol Appl 12:218-237

* Fontan S, Katul GG, Poggi D, Manes C, Ridolfi L (2013) Flume experiments on turbulent flows across gaps of permeable and impermeable boundaries. Boundary-Layer Meteorol 147:21-39

Francour P, Ganteaume A, Poulain M (1999) Effects of boat anchoring in Posidonia oceanica seagrass beds in the Port-Cros National Park (north-western Mediterranean Sea). Aquat Conserv: Mar Freshw Ecosyst 9:391-400

* Gacia E, Duarte CM (2001) Sediment retention by a Mediterranean Posidonia oceanica meadow: the balance between deposition and resuspension. Estuar Coast Shelf Sci 52:505-514

Giakoumi S, Halpern BS, Michel LN, Gobert S and others (2015) Towards a framework for assessment and management of cumulative human impacts on marine food webs. Conserv Biol 29:1228-1234

Gobert S, Lepoint G, Pelaprat C, Remy F, Lejeune P, Richir J, Abadie A (2016) Temporal evolution of sand corridors in a Posidonia oceanica seascape: a 15-years study. Mediterr Mar Sci 17:777-784

*Ganata TC, Serra T, Colomer J, Casamitjana X, Duarte CM, Gacia E (2001) Flow and particle distributions in a nearshore seagrass meadow before and after a storm. Mar Ecol Prog Ser 218:95-106

Gruber RK, Kemp WM (2010) Feedback effects in a coastal canopy-forming submersed plant bed. Limnol Oceanogr 55:2285-2298

*Hansen JCR, Reidenbach MA (2012) Wave and tidally driven flows in eelgrass beds and their effect on sediment suspension. Mar Ecol Prog Ser 448:271-287

*Hansen JCR, Reidenbach MA (2013) Seasonal growth and senescence of a Zostera marina seagrass meadow alters wave-dominated flow and sediment suspension within a coastal bay. Estuaries Coasts 36:1099-1114

* Hastings K, Hesp P, Kendrick GA (1995) Seagrass loss associated with boat moorings at Rottnest Island, Western Australia. Ocean Coast Manage 26:225-246

*Hendriks IE, Sintes T, Bouma TJ, Duarte CM (2008) Experimental assessment and modeling evaluation of the 
effects of the seagrass Posidonia oceanica on flow and particle trapping. Mar Ecol Prog Ser 356:163-173

Hovel KA, Lipcius RN (2001) Habitat fragmentation in a seagrass landscape: patch size and complexity control blue crab survival. Ecology 82:1814-1829

Hu Z, Suzuki T, Zitman T, Uittewaal W, Stive M (2014) Laboratory study on wave dissipation by vegetation in combined current-wave flow. Coast Eng 88:131-142

* Infantes E, Terrados J, Orfila A, Canellas B, Alvarez-Ellacuria A (2009) Wave energy and the upper depth limit distribution of Posidonia oceanica. Bot Mar 52:419-427

Infantes E, Orfila A, Simarro G, Terrados J, Luhar M, Nepf H (2012) Effect of a seagrass (Posidonia oceanica) meadow on wave propagation. Mar Ecol Prog Ser 456:63-72

Koch EW, Gust G (1999) Water flow in tide- and wavedominated beds of the seagrass Thalassia testudinum. Mar Ecol Prog Ser 184:63-72

Koftis T, Prinos P, Stratigaki V (2013) Wave damping over artificial Posidonia oceanica meadow: a large-scale experiment study. Coast Eng 73:71-83

Larsen TH, Lopera A, Forsyth A (2008) Understanding traitdependent community disassembly: dung beetles, density functions, and forest fragmentation. Conserv Biol 22: 1288-1298

* Lawson SE, Wiberg PL, McGlathery KJ, Fugate DC (2007) Wind-driven sediment suspension controls light availability in a shallow coastal lagoon. Estuaries Coasts 30: 102-112

* Leonard LL, Luther ME (1995) Flow hydrodynamics in tidal marsh canopies. Limnol Oceanogr 40:1474-1484

Leriche A, Pasqualini V, Boudouresque CH, Bernard G, Bonhomme P, Clabaut P, Denis J (2006) Spatial, temporal and structural variations of a Posidonia oceanica seagrass meadow facing human activities. Aquat Bot 84: 287-293

Lewis J (1968) Water movements and their role in rocky shore ecology. Sarsia 34:13-36

Lowe R, Kossef J, Monismith S (2005) Oscillatory flow through submerged canopies: 1. Velocity structure. J Geophys Res 110:C10016

Madsen JD, Chambers PA, James WF, Koch EW, Westlake DF (2001) The interaction between water movement, sediment dynamics and submersed macrophytes. Hydrobiologia 444:71-84

* Manca E, Cáceres I, Alsina JM, Stratigaki V, Townend I, Amos CL (2012) Wave energy and wave-induced flow reduction by full-scale model Posidonia oceanica seagrass. Cont Shelf Res 50-51:100-116

Menge B (1976) Organization of the New England rocky intertidal community: role of predation, competition, and environmental heterogeneity. Ecol Monogr 46:355-393

Milazzo M, Badalamenti F, Ceccherelli G, Chemello R (2004) Boat anchoring on Posidonia oceanica beds in a marine protected area (Italy, western Mediterranean): effect of anchor types in different anchoring stages. J Exp Mar Biol Ecol 299:51-62

Möller I, Mantilla-Contreras J, Spencer T, Hayes A (2011) Micro-tidal coastal reed beds: hydro-morphological insights and observations on wave transformation from the southern Baltic Sea. Estuar Coast Shelf Sci 92: 424-436

Montefalcone M, Chiantore M, Lanzone A, Morri C, Albertelli G, Bianchi CN (2008) BACI design reveals the decline of the seagrass Posidonia oceanica induced by anchoring. Mar Pollut Bull 56:1637-1645
Montefalcone M, Parravicini V, Vacchi M, Albertelli G, Ferrari M, Morri C, Bianchi CN (2010) Human influence on seagrass habitat fragmentation in NW Mediterranean Sea. Estuar Coast Shelf Sci 86:292-298

Nepf H (2012a) Flow and transport in regions with aquatic vegetation. Annu Rev Fluid Mech 44:123-142

*Nepf H (2012b) Hydrodynamics of vegetated flows. J Hydraul Res 50:262-279

Nepf H, Ghisalberti M, White B, Murphy E (2007) Retention time and dispersion associated with submerged aquatic canopies. Water Resour Res 43:W04422

*Neumeier U, Amos CL (2006) The influence of vegetation on turbulence and flow velocities in European salt-marshes. Sedimentology 53:259-277

* Ondiviela B, Losada IJ, Lara JL, Maza M, Galván C, Bouma TJ, van Belzen J (2014) The role of seagrasses on coastal protection in a changing climate. Coast Eng 87:158-167

*Patriquin DG (1975) 'Migration' of blowouts in seagrass beds at Barbados and Carriacou, West Indies, and its ecological and geological implications. Aquat Bot 1: 163-189

* Paul M, Bouma TJ, Amos CL (2012) Wave attenuation by submerged vegetation: combining the effect of organism traits and tidal current. Mar Ecol Prog Ser 444:31-41

* Peralta G, van Duren LA, Morris EP, Bouma TJ (2008) Consequences of shoot density and stiffness for ecosystem engineering by benthic macrophytes in flow dominated areas: a hydrodynamic flume study. Mar Ecol Prog Ser 368:103-115

* Peterson CH, Luettich RA, Micheli F, Skilleter GA (2004) Attenuation of water flow inside seagrass canopies of differing structure. Mar Ecol Prog Ser 268:81-92

* Pujol D, Colomer J, Serra T, Casamitjana X (2012) Response of submerged aquatic vegetation to turbulence: an experimental study. Estuar Coast Shelf Sci 114:23-30

* Pujol D, Casamitjana X, Serra T, Colomer J (2013a) Canopyscale turbulence under oscillatory flow. Cont Shelf Res 66:9-18

* Pujol D, Serra T, Colomer J, Casamitjana X (2013b) Flow structure in canopy models dominated by progressive waves. J Hydrol (Amst) 486:281-292

* Ricart AM, York PH, Rasheed MA, Pérez M, Romero J, Bryant CV, Macreadie PI (2015) Variability of sedimentary organic carbon in patchy seagrass landscapes. Mar Pollut Bull 100:476-482

Kos A, Colomer J, Serra T, Pujol D, Soler M, Casamitjana X (2014) Experimental observations on sediment resuspension within submerged model canopies under oscillatory flow. Cont Shelf Res 91:220-231

Sánchez J, Gazo M, Lorente A (2008) Diagnosis and analysis of the state of conservation of Posidonia oceanica in Cala Montgó and effects of anchors on meadow conservation. Technical report, Medes Islands Protected Area (Department of Environment) and Submón (in Catalan), Barcelona

Sanchez-Vidal A, Canals M, Calafat AM, Lastras G and others (2012) Impacts on the deep-sea ecosystem by a severe coastal storm. PLOS ONE 7:e30395

* Serrano O, Ruhon R, Lavery PS, Kendrick GA and others (2016) Impact of mooring activities on carbon stocks in seagrass meadows. Sci Rep 6:23193

Sokal RR, Rohlf FJ (1995) Biometry. WH Freeman, New York, NY

*Tanner JA (2005) Edge effects on fauna in fragmented seagrass meadows. Austral Ecol 30:210-218 
Thomas FIM, Cornelisen CD (2003) Ammonium uptake by seagrass communities: effects of oscillatory versus unidirectional flow. Mar Ecol Prog Ser 247:51-57

*Tigny V, Ozer A, De Falco G, Baroli M, Djenidi S (2007) Relationship between the evolution of the shoreline and the Posidonia oceanica meadow limit in Sardinian coastal zone. J Coast Res 23:787-793

Vacchi M, Montefalcone M, Bianchi CN, Morri C, Ferrari M (2010) The influence of coastal dynamics on the upper limit of the Posidonia oceanica meadow. Mar Ecol 31: 546-554

Vacchi M, Montefalcone M, Bianchi CN, Morri C, Ferrari M (2012) Hydrodynamic constraints to the seaward development of Posidonia oceanica meadows. Estuar Coast Shelf Sci 97:58-65

Editorial responsibility: Just Cebrian,

Dauphin Island, Alabama, USA van der Heide T, van Nes EH, Geerling GW, Smolders AJP, Bouma TJ, van Katwijk MM (2007) Positive feedbacks in seagrass ecosystems: implications or success in conservation and restoration. Ecosystems 10:1311-1322

*van Katwijk MM, Bos AR, Hermus DCR, Suykebuyk W (2010) Sediment modification by seagrass beds: muddification and sandification induced by plant cover and environmental conditions. Estuar Coast Shelf Sci 89:175-181

Walker DI, Lukatelich RJ, Bastyan G, McComb AJ (1989) Effect of boat moorings on seagrass beds near Perth, Western Australia. Aquat Bot 36:69-77

Z Zhu J, Matsuzaki T, Lee F, Gonda Y (2003) Effect of gape size created by thinning on seedling emergency, survival and establishment in a coastal pine forest. Forest Ecol Manage 182:339-354

Submitted: February 1, 2016; Accepted: February 11, 2017 Proofs received from author(s): March 29, 2017 